UNIVERSITY

OF DEBRECEN

FACULTY OF

HeALTH

NYÍREGYHÁZA

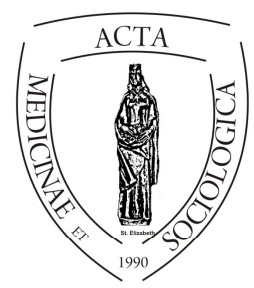

ACTA

MedSoc

Volume 7.

2016

\title{
Az alkotó-fejlesztő meseterápia integrációs lehetőségei lovasterápiás foglalkozásokon szorongó gyermekek terápiájában
}

\author{
Dr. Schéder Veronika \\ Debreceni Egyetem, Gyermeknevelési és Felnőttképzési Kar, \\ Pszichológiai és Gyógypedagógiai Tanszék
}

\begin{abstract}
The integrative possibilities of creative-developing fairy tale therapy and equestrian therapy for distressed children

The aim of the study is to provide health, social and helping professionals, as well as researchers with comprehensive and thorough knowledge on a complementary therapy method which is less or rather superficially known and has little accessibility in Hungary despite the fact that the need and necessity for it has been growing. Additionally, according to the data, the condition of those who are given the chance to participate in an equestrian therapy significantly improves, which underpins the efficiency of equestrian therapy. The presented cases show the process and outcomes of equestrian therapy with distressed children supported by creative-developing fairy tale therapy, too.
\end{abstract}

Keywords: equestrian therapy fairy tale therapy, distress

Absztrakt. Az alábbi tanulmány célja, hogy az egészségügyi, szociális és más, hasonló segítő szférában dolgozó szakemberek és tudományos kutatók számára közelebbi, egzakt ismereteket nyújtson egy olyan kiegészítő terápiás módszerről, amely Magyarországon 
kevéssé vagy nem pontosan ismert és körülhatárolt, elérhetősége korlátozott, pedig igénybevételének szükségét és szükségességét egyre többen érzik indokoltnak. Akiknek mégis megadatik a lehetőség, hogy lovasterápiás foglalkozásokon vehetnek részt, állapotukban többnyire jelentős (és más terápiás módszerekkel össze nem vethető) javulást tapasztalhatnak meg, így eredményeikkel alátámasztják a lovasterápia hatékonyságát. Az itt közölt esetbemutatással szorongó gyermekek lovasterápiás megsegítésének folyamatát és eredményeit kívánjuk szemléltetni, melyet alkotó-fejlesztő meseterápiás módszerrel támogattunk.

Kulcsszavak: lovasterápia, meseterápia, szorongás

DOI: $10.19055 / \mathrm{ams} .2016 .7 / 22-23 / 5$

\section{Bevezetés}

A lovasterápia egyrészt a ló-asszisztált foglalkozások, másrészt a kiegészítő terápiás foglalkozások körében megjelenő segítő tevékenység. Képesített lovasterapeutává ugyanúgy, mint a „metamorphoses” alkotó-fejlesztő meseterápiás módszer alkalmazójává Magyarországon akkreditált pedagógustovábbképzés formájában válhatnak azok a szakemberek, akik ehhez megfelelő alapképzettséggel (megfelelő szakos alapdiplomával) rendelkeznek. Ám míg a meseterápiás módszer alkalmazását külön jogszabályi háttér nem szabályozza, addig a lovasterápiás foglalkozások indítását, illetőleg a lovasterápiás praxis fenntartását igen (erről a lovas szolgáltató tevékenységekről szóló 14/2008. (XII. 20.) ÖM rendelet ad részletes tájékoztatást). Ezek a feltételek némileg megnehezítik a lovasterápiás tevékenység végzését, így hazánkban sajnálatos módon kevés olyan szakembert találni, aki nemcsak hivatalos végzettséggel rendelkezik, hanem tevékenységet is folytat, miközben a klientúra oldaláról úgy tünik, hogy munkájukra, erre a típusú, speciális kiegészító terápiás lehetőség igénybevételére évről évre egyre többen rászorulnának. Az alábbi tanulmány bemutatja a lovasterápia alkalmazási területeit, hatásmechanizmusát, módszertanát, majd egy konkrét terápiás eset ismertetésén keresztül az alkotó-fejlesztő meseterápia integrációjának egy lehetséges megjelenési formájába enged betekintést.

\section{A lovasterápia alkalmazási területei, módszerei, hatásmechanizmusa}

A lovasterápia együttesen aknázza ki a ló, a lovaglás és a lóval való foglalkozások, ló körüli teendők hatásait, egy komplex eljárás, amelynek elsősorban mozgásfejlesztő, gyógypedagógiai és pszichológiai vonatkozásai vannak (Bozori 2002; Györgypál 2006). Azoknak a gyerekeknek, fiataloknak és felnőtteknek teremt terápiás lehetőséget, akik valamilyen mozgásszervi, érzékszervi, mentális, nyelvi/beszéd- vagy szociális, pszichés problémával élnek. Lovasterápiás keretek között olyan szakemberek foglalkoznak velük, akik gyógytornász (/konduktor), 
gyógypedagógus, pszichológus, pszichoterapeuta vagy orvos képesítéssel rendelkeznek, valamint elvégezték a Magyar Lovasterápia Szövetség által akkreditáltatott lovasterapeuta-továbbképzést. A gyógytornász-lovasterapeutákat összefoglaló néven hippoterapeutáknak nevezzük, míg a gyógypedagógiai és a pszichológiai szakág képviselőinek titulusát a szükebb értelemben vett lovasterapeuta fogalom jelöli (hozzátéve, hogy gyógypedagógiai lovaglás és voltizsálás/lovastorna, vagy pedig ló-asszisztált pszichoterápia szakágon).

A lovasterapeuták hazánkban többnyire alapítványi keretek között vagy magánúton (egyéni vállalkozóként) dolgoznak, saját lovardában vagy egyéb, már müködő lovardához csatlakozva. A lovasterápiás ellátást az Egészségpénztárak egyelőre Magyarországon még nem finanszírozzák. A praxis nem engedélyköteles, de bejelentésköteles tevékenységi forma. A Magyar Kereskedelmi Engedélyezési Hivatal és a Nemzeti Élelmiszerbiztonsági Hivatal, továbbá a Magyar Lovasterápia Szövetség eljárásrendszerén keresztül, a terápiás foglalkozásokba bevont ló levizsgáztatásával (amelyet ötévente ismételni szükséges), a telephelyre vonatkozó megfelelö feltételek megteremtésével (a jogszabályban meghatározott infrastrukturális és személyi háttér megléte esetén) végezhetö.

A lovasterápia a 3. életévüket betöltött gyerekektől kezdődően egészen a felnőtt korosztályig nyitott, amennyiben nem áll fenn olyan állapot a páciensnél, amely kontraindikálja a lovasterápiát. Utóbbi esetben ugyanis kárt is okozhat a lovon végzett munka. Kifejezett figyelmet érdemel pl. a csípő és a gerinc állapota, de különböző belgyógyászati kórképek is rizikófaktort jelenthetnek - ezekre részletesen e tanulmány keretei között nincs módunk kitérni, ugyanakkor minden lovasterapeuta feladata, hogy a klienssel történő első találkozás alkalmával informálódjon a lehetséges kizáró tényezőkről. A lovasterapeuta persze nem diagnosztizál. Bár vannak rá eszközei (1. pl. Bozori 2005), de a konkrét diagnózisokat mindig a megfelelö szakemberek, pl. gyógytornászok, gyógypedagógusok, pszichológusok, orvosok állítják ki. Ö (a lovasterapeuta) a képzettsége alapján arra hivatott, hogy a páciensröl kapott szakvéleményeket értelmezni tudja, azok ismeretében saját, de már lovon történő felmérései alapján megtervezze és kivitelezze a személyre szabott fejlesztéseket. Munkájának időtartama és hatékonysága - más terápiás eljárásokhoz hasonlóan - mindig az adott pácienstől, illetőleg a páciens (aktuális) állapotától függ. Általában azonban elmondható, hogy inkább hosszú távú terápiát végez.

A lovasterápia heti rendszerességü foglalkozások formájában valósul meg, egy-egy találkozás általában 30 perces lovon történő kezelést jelent. (Egyes esetekben, a kórállapot függvényében ez az időtartam rövidebb, 15-20 percre szabott, máskor valamivel hosszabb, 45-60 perc is lehet.) Ilyenkor egyénileg foglalkozunk a páciensekkel. Létezik azonban csoportos módszer is, amikor 2-3-4 fö részvételével dolgozunk egyszerre hosszabb ideig, 45-60 percig. 
Munkaterületünk egy zárt terület (az időjárás függvényében kinti füves/homokos pálya, illetőleg fedett lovarda). A foglalkozások egy lóvezető segítségével, vezetett lovon valósulnak meg, ügyesebb (vagy felnőtt) lovasok esetén futószáron. Munkánkat szerencsés esetben két további segítő is kíséri (pl. a hippoterápiában a ló jobb és bal oldala mellett haladva). A kezelések során alapvetően a ló lépés jármódját alkalmazzuk, ritkábban az ügetést.

A ló hátára többnyire szivacsot és voltizshevedert teszünk, nem nyerget (1. ábra). Ez azt a célt szolgálja, hogy a lovon ülő minél közvetlenebb érintkezésbe kerülhessen a ló testével, a lovas izmai találkozzanak a ló izommozgásával. Így jobban érezhető az állat testének melegsége, ami kellemes, megnyugtató érzéseket ad, továbbá oldja az izomfeszültségeket.

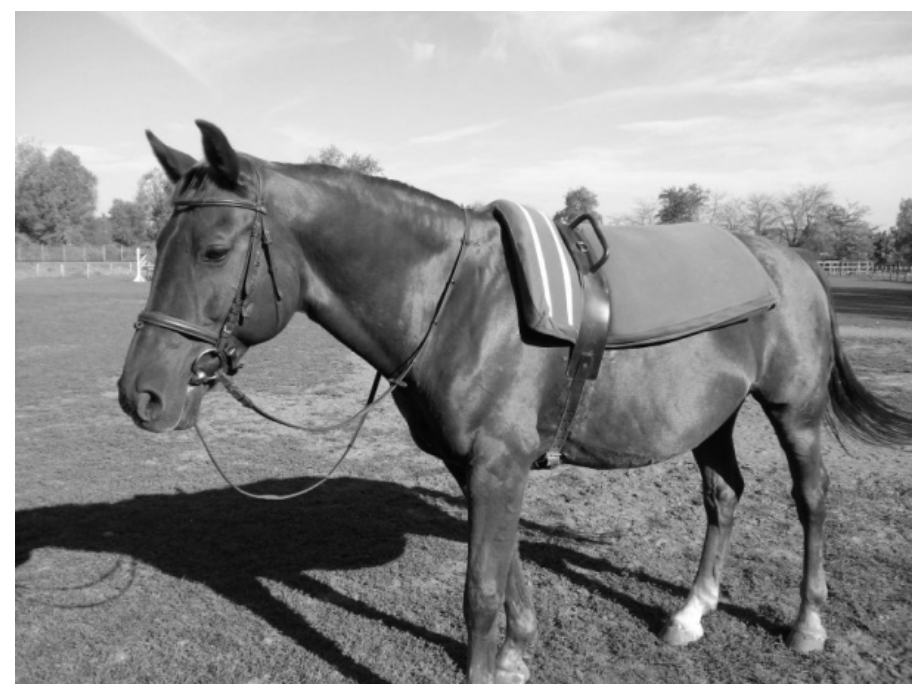

1. ábra: Szivacs, voltizsheveder

Elsősorban és alapvetően a ló által közvetített mozgásimpulzusok jótékony hatásait, valamint a ló hátán kivitelezhető mozgásos feladatok végrehajtásából fakadó lehetőségeket használjuk ki, tehát magának a ló mozgásának van a rajta ülő páciensre nézve terápiás értéke. A ló lépő mozgása által közvetített ingerek folyamatosan stimulálják a ló hátán ülő kliens vesztibuláris rendszerét, a teljes idegrendszert és az összes (kisebb-nagyobb) izomcsoportot. A ló háromdimenziós, ritmikus mozgása olyan gazdag ingereket nyújt, mint amilyeneket a magzat az anyaméhben érzékelt. Amennyiben egy gyermeknél pl. koraszülöttség (vagy egyéb, a magzati életben vagy a születés körül elszenvedett károsodások) következtében ezeknek az érzéki tapasztalatoknak a folyamata megszakadt, a 
lovasterápia azokat pótolhatja, helyettesítheti. Fejleszti az idegösszeköttetéseket, vagy akár új idegsejtmüködéseket is beindíthat (Büki 2006). A ló mozgása a laza, petyhüdt izomzatot megerősíti, a görcsös, feszes izomcsoportokat viszont ellazítja - a testi oldódás pedig párhuzamosan lelki oldódást is eredményez: a lovon ülő számára kinyílik a világ, ő maga is kezdeményezőbbé, kommunikatívabbá válik. A terápiás ló azon kívül, hogy mozgásmintát szolgáltat és a mozgásimpulzusokon keresztül a lovas különösebb aktivitása nélkül is gyógyítja a fizikumot (áttételesen pedig a pszichét), különféle szociális viselkedésmintákat is közvetít, amelyen keresztül a páciensek felismerhetik saját kedélyállapotukat, hangulatukat, ezzel elősegítve a társas kapcsolataik alakulását, fejlödését. Úgy is fogalmazhatunk, hogy a szenzomotorikus gyakorlatok arra késztetik a testet, hogy érzékelje saját magát, a szocio- és pszichomotorikus gyakorlatok pedig elősegítik a kapcsolatok létesítését és az érzelmek közlését (Hartje 2012). A ló hátán különös módon szabadnak (felszabadultnak), függetlennek érezhetjük magunkat - de ugyanezek a körülmények másban épp a valakibekapaszkodás, a biztos pont érzetét alakíthatják ki. Mindenképpen növeli a saját erőnkbe, énünkbe vetett hitet, az önbizalmunkat, önbecsülésünket, önértékelésünket: ahogy egy 6-700 kg-os állattal együttmüködve dolgozunk, ügetés közben még a lépő jármódnál is jobban átélve a közös mozgásdinamika összhangját és az afölött aratott sikerélményt - nevezetesen, hogy valóban „megültük” a lovat. A terápiás ló pszichés adottságainál fogva ,jégtörő-funkicót” tölt be: elősegíti, támogatja, fenntartja a kooperáció kialakulását a ló-terapeuta-kliens háromszögben (aminek eredményei később „kivihetőek” a kliens külső kapcsolataiba és ott felhasználhatóak). Lehetőséget ad a testi kapcsolatra, ezáltal áttételeket indukálhat, projekciós felületet teremthet. A freudi személyiségszerkezetet (id-egosuperego/ösztön-én-én-felettes-én) remekül leképezheti ez a „triász”, amelyben a ló mint ösztön-én, a terapeuta mint felettes-én szélsőségei között a kliens én-je szabadon, de biztonságosan fedezheti fel önmagát. Végül, de nem utolsó sorban: a terápiás ló mindig tükör. Akkor is, ha éppen nem ugyanazt „látjuk benne”, mint amit magunkban érzékelünk - ilyenkor ugyanis kiegészít, kompenzál, de ezáltal is tükröz, tükrözi azt, amiről mi magunk megfeledkezünk, nem veszünk tudomást, olykor talán nem is ismerünk.

A fentiekben felvázolt fizikai és pszichológiai hatások a foglalkozások időtartama alatt mindvégig jelen vannak, és szinte észrevétlenül is "teszik a dolgukat". Meghatározott esetekben a pácienseknek megtanítjuk a voltizsálás gyakorlatait, azok leegyszerüsített változatát, amelyeket aztán álló és lépő lovon gyakorolnak. A lóra ülés ténye már önmagában véve is egy olyan helyzetet teremt, melyben a megváltozott képességü, sérült, beteg páciens megélheti a másokkal való egyenrangúság, illetőleg részben a felülemelkedés élményét (amennyiben szimbolikusan úgy tekintünk a lovon ülő helyzetére, mint aki aktuálisan magasabban pozicionált a földön járó embereknél). Egy-egy voltizsgyakorlat kivitele- 
zése pedig óriási sikerélmény lehet, ami újfent növelheti a páciens önbizalmát. Különböző eszközök bevonásával időközben még további lehetőségeket is kiaknázunk a kognitív funkciók (érzékelés, észlelés, emlékezet, figyelem, gondolkodás), a beszédfejlesztés, a motoros és orientációs képességek, az érzelmi állapot, az akarati cselekvések befolyásolása, a szocializáció elősegítése stb. érdekében. Valójában minden olyan eszközt és lehetőséget bevonhatunk és felhasználhatunk a foglalkozásainkon, amelyet a hagyományos gyógytornában, a gyógypedagógiai, logopédiai vagy pszichológiai terápiákon szokás - adaptálva őket a speciális környezethez, körülményekhez.

\section{Néhány szó a „metamorphoses” alkotó-fejlesztő meseterápiás módszerről}

A meseterápiában a ló helyett (esetleg a ló mellett) mesével kísérjük a pácienst egy adott élethelyzetében vagy életszakaszában, $\mathrm{s}$ a meséken keresztül nyújtunk viselkedésbeli és gondolkodásbeli mintákat számára (Boldizsár 2014). Felnőttek esetében gyakran az általuk hozott kedvenc mesével dolgozunk, kisgyermekeknek magunk keresünk az adott életszituációhoz illö, illeszkedő mesét, melyben a hős ugyanolyan vagy hasonló problémája kapcsán indul útnak, küzd meg próbatételekkel, de nem akad el, hanem végig is járja ezt az utat, megtalálja hozzá azokat a segítőket és azt a tudást, amely valójában mindannyiunké, csak pillanatnyilag (még) kissé ,vakok” és „süketek” vagyunk rá, hogy mindezeket saját magunkban észrevegyük (Boldizsár 2010). A meseterápia lelki szemünk és fülünk felnyitásában segít. Nem egy rajtunk kívül álló utat mutat tehát. Minden, ami a mesében történik, az a saját tudatunkban megy végbe - mi magunk vagyunk a mese, s mi magunk vagyunk a mese szereplöi is (Pressing 2011). A módszer elnevezésében szereplő ,alkotó-fejlesztö” jelző arra utal, hogy e belső (látszólag észrevétlen, spontán) átalakulás közben a történetek feldolgozását konstruktív, játékos keretek közé illesztett feladatokkal, vagy valamilyen képzőmüvészeti, alkotó tevékenységgel egészítjük ki, támogatjuk meg.

A mesék varázsereje azáltal bontakozik ki, hogy szimbolikus, de talán még pontosabb úgy fogalmazni, hogy képi (jobb agyféltekés) úton szólnak hozzánk. Nem az értelmet, hanem az érzelmeket célozzák, méghozzá a képzelet és a fantázia mozgósításával. Mindannyian tapasztaltuk már, milyen nehéz bizonyos érzelmeinket szavakba önteni. A képek és szimbólumok sokkal többet kifejeznek a nyelv börtönébe zárt szavaknál. Aki vállalja, hogy belép a mesék kapuján, olyan mély belső világokba juthat el, ahol talán „még a madár se járt” (Pápes 2013).

Egy hallott mese befogadásakor a gyerekek önkéntelenül is mindig azzal a mesehőssel azonosulnak, illetőleg a mesének épp arra a vonulatára reagálnak érzékenyen, amelyre a saját kis élet-történetünk (vagy épp megakadásuk) szempontjából a legnagyobb szükségük van. A történetek ugyan univerzálisak, de mondanivalójukhoz mindenki egyedi utakon jut el, a hozzájuk kapcsolódás mindig egyedi (Boldizsár 2013). Elvezetnek a forráshoz, de abból inni mindenki 
csak saját maga képes. Ilyen módon a gyerekek lehetőséget kapnak arra, hogy a mesék feldolgozásával párhuzamosan legyőzhessék félelmeiket, kompenzálják kicsiségüket, felszámolják szégyenérzetük okát - a mese egészen egyszerüen kárpótlást nyújthat nekik nemcsak a valós, hanem a vélt fogyatékosságaikért is (Kádár 2012).

\section{Esetbemutatás}

Esetbemutatásunk alanya egy 6 éves, nagycsoportos óvodás kisfiú, aki erős szorongással, néhány konkrét félelemmel, visszafogott és kevés kommunikációs szándékkal érkezett hozzánk. Szülei azért kértek lovasterápiás segítséget, mert elmondásuk szerint gyermeküknek az óvodában sem voltak barátai, nem kezdeményező, de nem is reagáló, nehezen illeszkedik be a társas kapcsolatokba, s már előre tartanak attól, mi lesz, ha a következő ősszel iskolába megy ott már (ahogy ők fogalmaztak) muszáj megszólalni, válaszolni a tanító néninek... A lovasterápiától némi oldódást reméltek, bátorságnövelést, önbizalomerősítést vártak. Fontos körülmény, hogy a gyermek megsegítésében nemcsak kiegészítő, hanem fö vonal volt a lovasterápia, így a megtapasztalt és elért eredmények tisztábban támasztják alá, hogy jelenlétünk terápiás lovammal, Pazarral valószínüleg nem elhanyagolható faktorként segítették a változások elérését: egy nyílt, kommunikatív és nem utolsó sorban bátor, bevállalós, remek kisfiú lett belöle (miközben tanulmányait tekintve is osztályelső volt mindjárt az általános iskola első osztályában).

Kisebb megszakításokkal körülbelül 1,5 évnyi lovasterápiás együttmüködésünk során ezzel a kisfiúval sikerült végigvinnem a lovas közegbe ágyazva egy hosszú meseterápiát: fejezetenként feldolgoztuk Frank L. Baumtól az Óz, a csodák csodája c. teljes mesét. Heti egy alkalommal találkoztunk, 30 perces foglalkozások keretében, eleinte vezetett, lépő lovon dolgozva, később futószáron, lépésben és ügetésben. A lovasterápiás körülmények mellett, azokhoz adaptálva a „metamorphoses” alkotó-fejlesztő meseterápiás módszert alkalmaztam (Boldizsár 2010). A mesék világa által felkínált tudattalan, avagy tudatalatti öngyógyító folyamatot szerettem volna elősegíteni az egyébként nagyon is tudatos meseválasztásommal: felkínálva neki a lehetőséget $\mathrm{s}$ a módot a „bátor oroszlánná” való átváltozáshoz. Az átalakulás szépen, lassan megtörtént. Az alábbiakban röviden bemutatjuk azt a lovas- és meseterápiás utat, amit - ö lovam hátán ülve, jómagam mellettük gyalogolva - közösen bejártunk:

A meseterápiás munka megkezdése előtt néhány hétig csak magával a lovas közeggel ismerkedtünk. Az első foglalkozáson a kisfiú 20 percen keresztül görcsösen szorította a voltizsheveder kapaszkodóit, merev, vállövi, kapkodó légzéssel, görnyedt háttal. Valójában kezdtem azt érezni, jobban tenném, ha leszállítanám a lóról, mert a végén többet fogok ártani a gyermeknek, mint használni... Ám kérdésemre, hogy szeretné-e befejezni a lovaglást, csak rázta a fejét, hogy 
nem-nem, folytatni akarja. Tipikus helyzet, talán felnőttként is többen szembesültünk már vele: amikor valami nagyon vonzó dolgot szeretnénk kipróbálni, bár egyben rettenetesen félünk is tőle - a szívünk a torkunkban kalimpál, a gyomrunk majd' kiugrik a helyéből, de azért mi mégis, mégis azt akarjuk... Mindezt átérezve és megértve úgy döntöttem, elengedem a bizonytalanságomat, tehát folytattam a foglalkozást. Aztán egyik percről a másikra egyszer csak feloldódott a kisfiú: kiengedett a görcs, ellazultak az izmok, harmonizálódott a légzése, megszünt a kapkodó zihálás. (Hiába: erőteljes érzelmeket hosszú ideig fenntartani úgyis képtelenség...) Felemelö érzés volt látni és megélni ezt a szép megküzdési folyamatot és átmenetet.

A következő hetekben az érzelmekkel foglalkoztunk. Képkártyák segítségével beszélgettünk először az emberi alapérzelmekröl: a kártyákon látható emberek arckifejezéseiről kellett felismernie, vajon milyen állapotban vannak, hogyan éreznek a szereplők, majd lovakat ábrázoló képek kerültek elő, és az volt a feladat, hogy próbálja meg kitalálni, vajon a lovak hogyan érzik magukat a különböző helyzetekben (párosítsuk össze az ő állapotaikat a már azonosított emberi érzelmekkel). Az emberi érzelmeket páciensem jól felismerte és helyesen azonosította - természetesen csak rövid, egy-egy szavas illedelmes válaszokkal. Ezután beszélgetést kezdeményeztem arról, hogy ő mikor szokott nevetni, szokotte esetleg félni... Ha nekem nem akarja elmondani, akkor súgja meg Pazarnak, megígérem, hogy nem figyelek oda. (A gyerekek gyakran könnyebben nyílnak meg egy állatnak, adott esetben a terápiás lónak, mint egy embernek, a terapeutának.) Mosolygott játékos felvetésemen, felnőttesen ,vette a lapot” és végül nyíltan kimondta: igen, szokott félni, például akkor, amikor rosszat álmodik: belekerül a számítógépbe...

A következő foglalkozásunkon kevésbé volt kommunikatív, viszont annál bátrabb a voltizsgyakorlatok kivitelezésében: lépésben is megcsinálta a malomgyakorlatot (ez egy teljes fordulat a ló hátán: oldalülés, háttal ülés, újabb oldalülés és visszaérkezés elöre - közben el kell engedni a kapaszkodókat, vagyis cserélgetni rajtuk a fogást, magasra emelni és áttenni a lábakat egyik oldalról a másikra, nem könnyü feladat). Észrevettem a szeme alatt egy zöldes foltot, megkérdeztem, mi történt vele. Megtudtam, hogy elcsúszott az uszodában és megütötte. Fájt? - kérdeztem. Mire ő: „egy kicsit kellemetlen volt”. Én azt hiszem: eléggé fájhatott... De a legközelebbi terápián még közelebb kerültünk ezeknek a valódi, mély érzéseknek a bátrabb verbalizálásához. Egy új tornagyakorlatot tanítottam: hasonfekvés a lovon lépés közben. Ekkor kimondta: „egy kicsit félek". A keresztezett mozgásoknál (fogd meg a jobb kezeddel a bal bokádat) ismét közölte, hogy nem jó érzés lenézni, mert „téliszonya” van. Nem bántam! A következő héten már ügettünk is futószáron! Öszintén szólva számoltam vele, hogy esetleg megijed a lendületesebb mozdulatoktól, de kifejezetten élvezte és 
fülig ért közben a szája. Időközben a foglalkozásokba be-beiktatott légzőgyakorlatokat is egyre mélyebb levegővétellel, egyre ellazultabban csinálta.

Az egyik alkalommal játszottunk olyat, hogy ellovagoltuk egy napját: a reggeli felkeléstől az esti lefekvésig. A ló hátán kellett utánozni a mozdulatokat, pl. hogyan nyújtózkodik az ágyban, hogyan mosakodik, hogyan kormányozza apa az autót, miközben mennek az oviba. Imitáltuk az ovis foglalkozásokat is, volt számolás, verstanulás, a kedvenc ebédek felsorolása, azután jött az ebéd utáni csendes pihenő. Utóbbit a lovon úgy kiviteleztük, hogy kértem, hasaljon rá Pazar nyakára, kicsit be is csukhatja a szemét. Némi csendes lépés után „,felkeltettem”. Ekkor spontán módon megszólalt, hogy még jó is, hogy felkeltettem, mert... és magától elkezdte mondani, hogy mit álmodott. Egy szörnnyel álmodott, aki be akarta kapni. Azaz: be is kapta öt. Aztán ezt a szörnyet még bekapta egy másik szörny. Kérdeztem, milyen volt, hasonlított-e valamire vagy valakire. Mint egy egér - válaszolta. De volt szarva is. És mondott valamit? - tudakoltam tovább. Nem. Csak tátotta a száját - „csak ennyire volt képes”. Még megkérdeztem, hogy ez neki milyen érzés volt. Azt válaszolta, hogy ijesztő. Egy még későbbi foglalkozásunkon le is rajzolta egy „,szellemes/szörnyes” álmát a lépő ló hátán. Ez az álma arról szólt, hogy kergette öt egy szellem, és futott a napocska felé, bár a napocska is szörnynek nézett ki... Úgyhogy igazából azt sem tudta, hová fusson, és ekkor valami láthatatlan üvegfalba ütközött. Aztán az lett a vége, hogy megette öt a szellem. Ekkor megkérdeztem: nem lett volna-e mégiscsak jobb a napocskához menni? Mire ő: de igen, de nem lehetett, mert a láthatatlan üvegfal ott volt közöttünk. Ráadásul végül a napocskát is megette a szörny. (A végére már szörnynek nevezte a szellemet.)

Ezeket az álomtörténeteket azért tartottam érdemesnek bemutatni, mert jól szemléltetik, hogy a terápiás folyamat során hogyan kezdett el lassanként megnyílni ez a kisgyerek, aki találkozásunk kezdetén még olyan erősen magába zárkózott és mélyen elfojtotta a félelmetes érzéseit. Sajnos sok családban „divat”, hogy az érzelmeket el kell nyomni. Erre tanítják már az egészen kicsi gyerekeket is. Gondoljunk csak arra, amikor a kisbaba csak bőg és bőg - a felnőtteket ez rettenetesen idegesíti, mindent megtesznek annak érdekében, hogy minél előbb hagyja abba a sírást. Pedig a csecsemőnek még a sírás az egyetlen kommunikációs eszköze. Ilyen korán kezdődik tehát az érzelmek kifejezésének letiltása. Később folytatódik olyasmi intelmekkel (különösen kisfiúk nevelése kapcsán), mint pl.: „Most mit bőgsz? Csak a lányok nyafognak ilyesmiért!”, „Menj a szobádba, amíg le nem higgadsz, és csak akkor gyere ki, ha már mosolyogni tudsz!" stb. Pedig, ha az érzelmek nem kaphatnak szabad áramlást, akkor vagy betokozódnak (ebből lehetnek a későbbiekben ,jó kis” pszichoszomatikus betegségek), vagy közvetett módon, váratlan helyzetekben törnek a felszínre (ekkorra azonban már irtózatosra duzzadt energiával, pl. egy hisztiroham vagy verekedés formájában). Az érzelmeknek az a természetük, hogy kikívánkoznak - azt kellene 
megtanítani a gyerekeknek, hogy szabad érezni, mert az érzések természetesek, majd fokozatosan kialakítani bennük ezeknek az érzelmeknek a „hőfokszabályozó" gombjait (Cohen 2015).

Ezek után kezdtünk el foglalkozni a mesével. Az álom és a mesei szimbólumok nyelve ugyanis nagyon hasonló: a racionális tudat világából (ami a ,jéghegy csúcsa”) az érzelmi tudat világába repít (a tudattalanba) (Bagdy 2013). A mesehallgatás (és föként a meseterápia) képzelőerőt és fantáziatevékenységet kíván ez pedig kis páciensem eszköztárában egy ismerős és konstruktív stratégia volt.

A főszereplö kislány, Dorothy barátait hétről hétre játékosan elevenítettük meg. A mese első részének meghallgatása után (melyben megismerkedtünk a szereplőkkel és a kiinduló helyszínnel, majd a cselekményindító eseménnyel), gyermek páciensünk a lépő ló hátán rajzban fejezte ki mindazt, ami a meséből első benyomásként a legintenzívebben hatott rá. Elsőként a házat és a „citromvermet" rajzolta le (vö. ciklonverem). A szereplők nehezebben születtek meg. Olyannyira, hogy a Dorothyt nevelő Em néni le is maradt a rajzról, a föszereplő kislánynak csak a feje készült el (s még hetekig hallgattam, hogy „Dorothyt még mindig nem tudom elképzelni”). A második részből a sárga köves út ragadta meg a fantáziáját, miközben a „citromverem” további fontos kelléke maradt rajzának. A varázslónak jó nagy orrot pingált, és mellékesen megjegyezte, hogy azért nagy az orra, ,,mert sokat hazudott”. Következtek a mese kalandozásokat és segítőtársakkal való találkozásokat megjelenítő részei. A madárijesztővel történő megismerkedés kapcsán terményeket vittem a foglalkozásra: búzát, zabot, kukoricát, szalmát, szénát, lucernát - melyeket a kisfiú megtapogathatott, megszagolhatott, mi több, a zabot (mint a lovak kedvenc eledelét) meg is kóstolta. A szalmából és bálamadzagból aztán madárijesztöt készítettünk (akit persze Pazar lovam egyből fel is akart falni, oldott, mókás helyzetet teremtve ezzel). A bádogemberrel való találkozáshoz a lépő ló hátán ülve különböző anyagokat kellett kitapintania csukott szemmel egy, a voltizsheveder kapaszkodójához kötött zsákban (pl. müanyag kupak, fadarab, kavics, papír, vatta stb.), így ismertettem meg a bádoggal, amiből Dorothy barátja is készült. A berozsdásodott bádogember szerepére megkérve ôt egy-egy testrészét a varázs-lovaglópálca segítségével megérintve képletesen beolajoztuk és (a ló hátán kivitelezhető tornagyakorlatokkal) át is mozgattuk. Beszélgettünk a bádogember hiányzó szívéről: mire jó a szívünk, mit csinálunk vele? „Szeretünk” - hangzott a válasz. Mikor megkérdeztem tőle, számára milyen érzés az, amikor szeret valakit, egyáltalán hol érzi a testében azt, amit érez, azt felelte: olyan, mintha három hangya ütközne a szívéhez és dobálóznának vele.

Lassan eljött az ideje a gyáva oroszlánnal való találkozásnak is, amikor a kisfiú kapott egy oroszlán-álarcot, hogy azt feltéve bújhasson bele az oroszlán börébe. Kíváncsi voltam rá, vajon ő milyen oroszlán lenne - $\mathrm{s}$ úgy gondoltam, az átalakulást és beleérzést még jobban elősegíti, ha valóban magára öltheti az 
oroszlán arcát. A foglalkozás kezdetén kérdésemre kissé bizonytalanul azt válaszolta, hogy ő nem lenne olyan gyáva, mint a mesebeli oroszlán, de azért nem is lenne bátor. Viszont, miután jó sokat tornáztunk és ügettünk aznap, s a foglalkozás végén újra ráadtam az álarcot és újra nekiszegeztem a kérdést, hogy most milyen oroszlán lenne, mókázva, kissé színpadiasan így felelt: „Egy fáradt oroszlán." Utóbbi történet úgy látszik, jó nyomot hagyott egyébként benne - a kalandozások során már érezhető volt szimpátiája a gyávának mondott, magát gyávának hitt, de egyre inkább csak annak tünő oroszlánnal. Rendkívül élvezte például, amikor a mese szerint ez az oroszlán a hátára vette kis barátait és úgy ugrott át velük egy szakadékon. Ekkor kerültek elő a körkarámba nálunk is az akadályrudak, amelyeken ügetésben járóiskoláztunk, s Pazar csak úgy röpítette a hátán kis lovasát. Felemelő volt látni az összhangjukat, a felszabadultságukat. A ló és a lovas egymás iránti tökéletes elfogadását és csodás harmóniáját.

A mese következő fejezetei mindenféle kalandok és próbák elé állították a jóbarátokat. Az egyik alkalommal marcangok (szörnyek) támadták meg őket. Ekkor a madárijesztőnek támadt egy jó ötlete, hogyan szabadulhatnának meg tölük, és ez be is vált, a kis csapat megmenekült támadóitól. Miután a történetnek ezt a részét elmeséltem, a kisfiú első rekaciója az volt, hogy milyen okos ötlettel állt elő ez a madárijesztő, miért is kellene neki agy... A marcangok lerajzolásán sokáig, aprólékosan dolgozott a lépő ló hátán.

Minden foglalkozást úgy vezettem fel, hogy felelevenítettük közös történetünk már ismert eseményeit. Természetesen ahogy telt az idő, egyre több részletet kellett megjegyezni, észben tartani. Éppen ezért az egyik héten meg is dicsértem kis páciensemet, milyen jó a memóriája. Ez a megjegyzésem aztán meghatározott asszociációkat indított el benne: „Még arra is emlékszem, amikor a kistestvérem megszületett!" (Három fiúgyermek van a családban, ő a legidősebb testvér.) Kíváncsi voltam, vajon mire emlékszik abból az időből. Például arra, hogy milyen pici volt a testvére (mutatta, hogy a térdéig ért), illetve, hogy ,anya akkor még vezetett autót”. Ennél a pontnál óhatatlanul eszembe jutott a legelső mesefeldolgozó foglalkozásunkon készített rajzáról hiányzó Em néni...

A mese további próbatételeit is alkotó-fejlesztő feladatokkal együtt dolgoztuk fel. Amikor a kis csapatnak egy erős sodrású folyón kellett átkelniük, a lépő ló hátán ülve papírhajót hajtogattunk, majd fadarabokból és bálamadzagból tutajt kötöztünk. Amikor egy pipacsmező állta útjukat - nincsenek véletlenek... -, épp abban az évszakban jártunk, amikor a pipacsok virítottak körülöttünk, módunk volt hát megtapintani, megszagolni ezeket a kis virágokat, és mindjárt azt is megtanultuk róluk, hogy mérgező növények a lovak számára. Ezzel párhuzamosan azon a foglalkozáson több mérgező növénnyel is megismertettem a kisfiút, melyek ott, helyben, a karám szélén nyíltak - ilyenkor jól be lehet mutatni a gyerekeknek, hogy a lovak milyen okosak: a legelön kiválogatják azokat a növényeket, amelyek a szervezetük számára hasznos táplálék, vitaminforrás, vi- 
szont látható, hogy vannak „szigetek”, melyeket érintetlenül hagynak, hiszen ösztöneik megsúgják nekik, mely növények elfogyasztása ártalmas, megbetegítő számukra. A pipacsmező a mesebeli szereplőket is elkábította erős illatával. A mesélés során némileg tudatos hangsúlyt helyeztem arra, hogy a gyengének és törékenynek tünő virágoknak is micsoda erejük lehet (akár a nagy és erős állatokat is elkábíthatják), továbbá, hogy a szintén kicsinek és jelentéktelennek látszó egérkék ha összeállnak és csapatot alkotnak, együttes erővel a saját testméretüknél és súlyuknál többször nagyobb teherrel is remekül elbírhatnak. Láttam, hogy a kisfiú „mesetranszban” figyelt... Ez alkalommal ismét áttört benne egy lelki gát. Szinte végigbeszélte nekem az egész foglalkozást! Egyszer csak elkezdett mesélni arról, hogy a kistestvérével mostanában mennyi baj van, nem akar rendesen enni, és az anyukájuk milyen sokat kiabál, még olyan is előfordult, hogy sírt is. Megkérdeztem tỏle, hogy ekkor ő mit csinált, illetve ez neki milyen érzés volt. Mondta, hogy ez neki bizony nagyon rossz. Ilyenkor felmegy a szobájába és még a fülvédőt is a fülére teszi. Megállapodtunk abban, hogy nyugodtan tegyen is így ilyen esetekben - hiszen a kiabálás nem neki szólt...

Nemsokára elérkeztünk Óz, a nagy varázsló birodalmába, Smaragdvárosba, ahol minden zöld színben pompázott. Mi is felcsatoltunk egy képzeletbeli védöszemüveget és azt játszottuk, hogy pl. „látok valamit, ami zöld...” - s ilyenkor sorolni kellett a környezetünkben fellelhető zöld színű dolgokat. Ezt a játékot jól össze lehet kötni a lószínek megtanításával: képkártyákról, illetve, ha szerencsénk van (s nekünk az volt) a körülöttünk legelő (karámozott) lovak különbözö színfelhozatalán keresztül. Közel jártunk már a történet végéhez (ezzel párhuzamosan a kisfiú szorongásainak feloldásához is), de azért a jutalmat nem adják könnyen. Dorothyékra még várt néhány meglepetés-kaland: a gonosz nyugati boszorkány, a vicsoriak, a farkasok, a varjak, a méhek és végül a szárnyas majmok seregeivel. Ekkor vált azonban igazán érezhetővé a mesebeli oroszlán nagy jelentősége számára. Hangsúlyozottan emlegette egy-egy veszélyhelyzetben, hogy „majd biztos az oroszlán elüzi őket”. Végül valóban szépen kirajzolódott, hogy a jóság mindig erösebb a gonoszságnál...

A mesének ez a befejezése a népmesetípusok közül az ún. varázsmesékre hasonlít (itt természetesen mümesével van dolgunk). Felépítésüket tekintve a varázsmesék olyan történetek, amelyek valamilyen kár vagy veszteség megélésével kezdődnek, a hős otthonról való távozásával folytatódnak, aki útja során segítőkkel találkozik, mágikus tárgyakat kap, melyek segítik öt az ellenséggel való megküzdésben. Mikor már visszatéröben van, gyakran újabb üldöztetés következik, ami kicsit megbonyolítja a cselekményszálat, de végül mégis megtörténik a megérkezés és a megérdemelt jutalom elnyerése. Ezek a mesék meseterápiás szempontból jó rokoníthatók a páciens aktuális élethelyzetével, vagy belső lelki fejlődésének drámájával (Boldizsár 2010). 
Sok érdekes kaland után fokozatosan egyre nyíltabb, beszédesebb, cselekvőbb és kezdeményezőbb lett az a kisgyerek, akivel valamikor önmagába zárva találkoztam. Azon a napon, amikor a mesénk utolsó fejezete következett, saját magától mondta ki a következő mondatot: "Valójában ez az oroszlán mindig is bátor volt, csak nem tudott róla." Így teljesedett be nála az azonosuláson keresztül a feloldódás.

És van itt még egy gondolat a szájából, ami különösképpen megfogott. Amikor megkérdeztem tőle, ki volt a legszimpatikusabb szereplő számára, Ózt, a nagy varázslót nevezte meg, mégpedig a következő indokkal: azért, mert nem egy elvont, különleges valaki volt, hanem egy egyszerü EMBER.

Sokat tanultam ettől a kisfiútól, talán az egyik legtöbbet. Vajon a nagy, okos és bátor felnőttek számára mi lenne a legvonzóbb egy varázslóban? Vajon csak én érzem-e úgy, hogy tengernyi tulajdonságát felsorakoztatnák, kivéve egyet, egyetlenegyet: valódi ember-mivoltát...? Pedig a varázslás titka nem mindig volna bonyolult. Csak nem kellene folyton-folyvást annyira megfelelni igyekeznünk (valódi érzéseink helyett „mütermékeket” gyártanunk, kirakatvilágban élnünk), annyira különlegesnek lennünk, annyira extrán teljesítenünk. (Jó magasra téve a lécet, természetesen.) Egyszerüen csak természetes, egyenes, nyílt, őszinte embernek maradnunk. Valódi önmagunknak. Amolyan: emberinek.

\section{Összegzés}

A mesék végén a mese befogadói mind-mind oda érkeznek „haza”, ahová nekik aktuális élethelyzetüknél fogva meg kell érkezniük. Szorongó tünetekkel érkezett gyermek páciensünk a lovasterápia befejeztével a városi lovasiskola csapatához csatlakozott, elkezdett „,rendesen”, nyeregben megtanulni lovagolni. Azóta is hetente jár edzésekre, immár szabadon, önállóan lovagol.

A lovas- és a meseterápia közös vonása, hogy olyan természetes közegbe vezetik be az embert, ami nem diszkriminál: a kliens ezáltal nem azt éli át, hogy ő beteg, valami „elromlott benne”, amit „meg kell szerelni”. A ló és a mese is közös kincsünk, minden emberé. Mindkét világ alkalmas arra, hogy elmossa a különbségeket, a határokat egészséges és sérült emberek között (gondoljunk csak arra, amikor egy kerekesszékes ember felül a ló hátára - attól kezdve nem látszik, hogy nem tud járni, egyenrangúvá válik a többi lovassal). Véleményünk szerint a két terápiás módszer eredményesen kombinálható a gyakorlati alkalmazásban.

Bár a „metamorphoses” alkotó-fejlesztő meseterápia a népmesék alkalmazására épül, a fentiekben egy mümese feldolgozásán keresztül mutattuk be azokat a lehetőségeket, amelyeket általában a varázsmesék közvetítésével van módunk megismerni. Tárgyválasztásunk - mint arra az egyik fejezetben utal- 
tunk is - szerkezeti felépítését tekintve véleményünk szerint mégis alkalmasnak bizonyult a varázsmesékkel történő rokonításra, ezáltal a mese gyógyító erőinek mozgósítására.

\section{Irodalomjegyzék}

1. Bagdy E. (2013): Félelmek, szimbólumok, terápiák. Budapest, Kulcslyuk Kiadó.

2. Boldizsár I. (2010): Meseterápia. Mesék a gyógyításban és a mindennapokban. Budapest, Magvető Kiadó.

3. Boldizsár I. (2013): Mesekalauz úton lévőknek. Életfordulók meséi. Budapest, Magvető Könyvkiadó.

4. Boldizsár I. (2014): Meseterápia a gyakorlatban. A metamorphoses meseterápia alkalmazása. Budapest: Magvető Kiadó.

5. Bozori G. (2002): Lovasterápia. Gondolatok és vázlatok a gyógypedagógiai lovaglás és lovastorna témaköréböl. Székesfehérvár, Polu-Press Kkt.

6. Bozori G. (2005): Lovasterápia. A gyógypedagógiai lovaglás eredményességének vizsgálata. Felmérések, vizsgálatok, megfigyelések. Pákozd, Kapaszkodó Alapítvány.

7. Büki Gy. (2006): A hippoterápia neurofiziológiai alapjai, In: Györgypál Zoltánné (szerk.), Hippoterápia. Balogunyom, Unicornis Egészségforrás Alapítvány. 36-62.

8. Cohen, L. (2015): Játékos nevelés. Budapest, Kulcslyuk Kiadó.

9. Györgypál Z.-né (szerk.) (2006): Hippoterápia. Balogunyom, Unicornis Egészségforrás Alapítvány.

10. Hartje, W. (2009): Lovasterápia. Budapest, Mezőgazda Kiadó.

11. Kádár A. (2012): Mesepszichológia. Budapest, Kulcslyuk Kiadó.

12. Pápes É. (2013): Királylányok, tündérek, boszorkányok. A nő három arca a mesében. Budapest, L'Harmattan Kiadó.

13. Pressing L.(2011): Szellemi tanítások a magyar népmesékben 2. Az élet vize. Budapest, Pilis-Print Kiadó.

\section{A szerző}

\section{Dr. Schéder Veronika PhD}

Nyelvész, gyógypedagógiai lovaglás és voltizsálás szakos lovasterapeuta, a „metamorphoses” alkotó-fejlesztő meseterápiás módszer pedagógusa. Főiskolai docens, a Debreceni Egyetem Gyermeknevelési és Felnőttképzési Kar, Pszichológiai és Gyógypedagógiai Tanszékének föállású oktatója. 
Debreceni Egyetem, Gyermeknevelési és Felnőttképzési Kar, Pszichológiai és Gyógypedagógiai Tanszék (4220 Hajdúböszörmény, Désány István u. 1-9.). Email: veronika.scheder@ped.unideb.hu 
